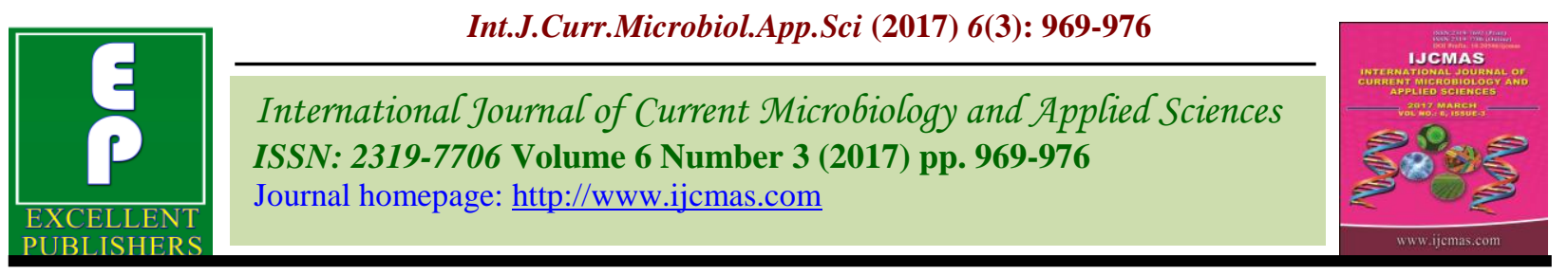

Original Research Article

https://doi.org/10.20546/ijcmas.2017.603.115

\title{
Adoption of Recommended Production Technology of Fennel Cultivation by the Farmers in Nagaur District of Rajasthan, India
}

\author{
Sunil Kumar Sharma ${ }^{*}$, N.K. Sharma ${ }^{2}$ and S. R. Kumawat ${ }^{1}$ \\ ${ }^{1}$ Agriculture Research Station, SKRAU Bikaner, Rajasthan, India \\ ${ }^{2}$ Department of Extension Education, SKNAU Jobner, Jaipur, Rajasthan, India \\ *Corresponding author
}

\section{A B S T R A C T}

Seed spices occupy prominent place in the total basket of spices of the country and play a significant role in our national economy. The group of spices account for about 37 per cent and 18 per cent of the total area and production of spices in the country, respectively. Fennel (Foeniculum vulgare) commonly known as 'Saunf' is an important and highly valued spice grown in India. This crop is widely grown throughout the temperate and subtropical region of the world for its aromatic fruits used in various food preparations

\section{Keywords}

Fennel growers, Adoption, Large, small and marginal farmers.

\section{Article Info}

\section{Accepted:}

18 February 2017

Available Online:

10 March 2017 such as soups, meat dishes, sauces, pastries, confectionaries, pickles, liquors etc. The fennel seeds are aromatic, stimulants and carminative. Rajasthan is the third largest producer of spices in the country and accounts for $12.48 \%$ of the total production of major spices. The major fennel producing districts of Rajasthan are Nagaur, Sirohi, Jalore, Dausa, Tonk, Sawai Madhopur and contribute above 90 per cent of area and production of fennel crop. Fennel is an important commercial cash crop of arid and semi arid region. There is a wide scope to improve and increase the fennel production and productivity by enhancing the knowledge and adoption of fennel production technology. The present study was conducted in eight villages (four villages from Mertacity tehsil and four villages from Degana tehsil) in Nagaur district of Rajasthan. A sample of 120 fennel growers was selected from these selected villages by using simple random sampling with proportion sample method. The results indicated that 28.33 per cent of the total respondents were in the medium level of adoption group, whereas 24.17 per cent respondents were in low adoption group and remaining 47.50 per cent fennel growers were be observed in the category of high level of adoption about fennel production technology. It was also observed that the extent of adoption among marginal farmers ranged from 57.50 to 100.0 per cent, whereas in case of small farmers and large farmers it was from 76.88 to 100.00 and 65.00 to 100.00 per cent in all the practices of fennel production respectively. Further, it was observed that large and small farmers had comparatively more extent of adoption than marginal farmers.

\section{Introduction}

India is known the world over as 'The Home of Spices', thus Spices and condiments need no introduction. The climate of the country is ideal for the growth of almost all spices. Spices are an important group of agricultural goods, which are virtually indispensable in the culinary art. They also play a significant role in our national economy and also in the economies of several spice producing, exporting and importing countries. India 
accounts for about $45 \%$ of the global spice exports. In India, from the point of view of both domestic consumption and export, spices are important commercial crops.

Seed spices occupy prominent place in the total basket of spices of the country and play a significant role in our national economy. The group of spices accounts for about 37 per cent and 18 per cent of the total area and production of spices in the country, respectively. Seed spices are mainly cultivated in the states of Rajasthan, Gujarat, Andhra Pradesh, and Madhya Pradesh. Among these fennel, coriander, cumin, fenugreek, and Ajwain are cultivated on sizeable acreage as compared to other spices. It is the world's largest producer, consumer and exporter of seed spices which are being cultivated widely in the country over different agro climatic zones. Seed spices are not only for home consumption but also for improving economic status of the farmers.

According to the International Organization for Standardization [ISO], there are about 109 spices and India produces as many as 75 in its various agro climatic regions. The term spices and condiments' applies to 'natural plant or vegetable products or mixtures in whole or ground form, which are used for imparting flavor, aroma and piquancy to the food items`. Spices are also being used within the country for flavoring foods and in medicines, pharmaceutical, perfumery, cosmetics and several other industries.

In India fennel is cultivated over an area of $1,00,000$ ha with the production of $1,43,000$ MT and productivity of $1,430 \mathrm{~kg} / \mathrm{ha}$ (National Horticulture Mission 2011-12).

Fennel (Foeniculum vulgare) commonly known as 'Saunf' is an important dominant and highly valued spice grown in India. This crop is widely grown throughout the temperate and subtropical region of the world for its aromatic fruits used in various food preparations such as soups, meat dishes, sauces, pastries, confectionaries, pickles and liquors etc. The fennel seeds are aromatic, stimulants and carminative.

Fennel oil is used as a flavoring agent in various culinary preparation, confectionary cordials and liquors. The percentage volatile oil in seed varies from 1.5 to 3.5 per cent. It contains 14-22 per cent protein with 12 to 18.5 per cent fat. It is used as a gripe water given to colicky infants. It is used to relieve bronchial spasms because of its antispasmodic properties. It targets the smooth muscles of the respiratory system, stomach muscles and intestines. Herbalists have used it for centuries to induce milk production in nursing mothers.

Rajasthan is the third largest producer of spices in the country and accounts for 12.48 of the total production of major spices. The state produces about $6,96,700$ tones of seed spices from an area of 9,01,628 ha with productivity $4,832 \mathrm{~kg} / \mathrm{ha}$.

The major fennel producing districts of Rajasthan are Nagaur, Sirohi, Jalore, Dausa, Tonk, Sawai Madhopur and occupy above 90 per cent of area and production of fennel crop. The average area, production and productivity of last five years are 13,404 ha, 11,085 tones, $827 \mathrm{~kg} / \mathrm{ha}$ respectively (Vital Agriculture Statistics (2011-12). So there are possibilities to increase its production by 40 to 50 per cent by adoption of improved technologies.

Fennel is an important commercial cash crop of arid and semi arid region. The production of spices is largely in the hands of small and marginal farmers and the level of productivity of most of the spices in India is below the level as prevailing in other countries. The lower productivity is attributed to lack of 
knowledge of high yielding varieties, ravages due to pest and diseases, inadequate postharvest technology and poor processing and storage facilities. Keeping this fact in view the present study entitled "The knowledge and Adoption of Recommended Production Technology of Fennel Cultivation by the Farmers in Nagaur District of Rajasthan" was undertaken.

\section{Research Methodology}

The present investigation was conducted in purposively selected Nagaur district of Rajasthan state highest area and great potential of increasing production and productivity. The researches himself is resident of the area and acquainted with the farmers and their local dialect which facilitated easy rapport building and authentic data collection from the farmers.

The selected consist of twelve tehsils, Out of which two tehsils namely Mertacity and Degana with maximum area under fennel crop production were selected for the study purpose. Separate lists of gram panchayats of the selected tehsils were prepared with the help of concerned 'patwaries' of the Mertacity and Degana tehsils. Mertacity and Degana tehsils comprise of 42 and 34 gram panchayats respectively. Out of which two gram panchayats (Dava and Jaroda kala) from Mertacity tehsil and two gram panchayats (Sanjoo and Chonsli) from Degana tehsil were selected on proportionate random basis. Initially, a complete list of all the major fennel growing villages of the selected tehsils was prepared in consultation with the personnel of revenue department and Agriculture department of the concerned area. From the list so prepared, 4 villages from each Tehsil were identified on the random basis under fennel crop. Thus, in all eight villages were selected for the present investigation. A comprehensive list of all fennel growers was prepared separately for all selected villages of identified tehsils. In preparing the list, the help of revenue personnel and agricultural supervisor of the concerned area were taken for authenticity and counter check of information. Then after, the farmers were categorized in to three categories i.e. large, small and marginal farmers. Following the procedure laid down above a sample of total 15 respondents i.e. 5 in each category from every selected village was drawn randomly. Thus the study sample for the present investigation was comprised 120 respondents (i.e. 60 from each Tehsil). Keeping in mind the objectives of study, the interview schedule was developed for the collection of data from the selected respondents.

\section{Adoption of farmers about recommended fennel production technology}

This part of the chapter deals with level of adoption of improved practices of fennel production technology by the farmers. In the modern era new ideas are being invented by agricultural scientists and put to use by farming communities but all the innovations are not being adopted by many of the members of a social system. Adoption of an innovation depends on many factors which exert influence on the decision of farmers. It is assumed that if an individual has more knowledge about different aspects of technologies, he is likely to adopt the innovations with higher speed. Several transfer of technology (TOT) programmes are in operation to help farmers to adopt the new technologies in our country but still there is a wide gap between the technology available and its adoption by the farming community. Keeping this in mind an attempt has been made to know the level of adoption of improved practices of fennel production technology in the study area. The results are presented in the subsequent tables. 
Distribution of respondents on the basis of their level of adoption

To get an overview of adoption level, the respondents were divided into three groups viz., (i) low level of adoption $(<21.35)$ (ii) medium level of adoption (21.35 to 29.56) and high level of adoption (>29.56). The groups were formulated on the basis of calculated mean and standard deviation of the adoption scores obtained by the respondents. The results are presented in the table 1 .

Table.1 Distribution of respondents on the basis of level of adoption of practices of recommended fennel production technology

\begin{tabular}{|c|c|c|c|c|c|c|c|c|c|}
\hline \multirow[t]{2}{*}{ S.No. } & \multirow[t]{2}{*}{ Adoption level } & \multicolumn{2}{|c|}{$\begin{array}{c}\text { Marginal } \\
\text { farmers }\end{array}$} & \multicolumn{2}{|c|}{ Small farmers } & \multicolumn{2}{|c|}{ Large farmers } & \multicolumn{2}{|c|}{ Total } \\
\hline & & $\mathbf{F}$ & $\%$ & $\mathbf{F}$ & $\%$ & $\mathbf{F}$ & $\%$ & $\mathbf{F}$ & $\%$ \\
\hline 1 & Low (21.36) & 20 & 50.00 & 5 & 12.50 & 4 & 10.00 & 29 & 24.17 \\
\hline 2 & $\begin{array}{c}\text { Medium } \\
(21.35 \text { to } 29.56)\end{array}$ & 11 & 27.50 & 11 & 27.50 & 12 & 30.00 & 34 & 28.33 \\
\hline 3 & High (29.56) & 9 & 22.50 & 24 & 60.00 & 24 & 60.00 & 57 & 47.50 \\
\hline & Total & 40 & 100.00 & 40 & 100.00 & 40 & 100.00 & 120 & 100.00 \\
\hline $\begin{array}{l}\mathrm{F}=\text { frequel } \\
\%=\text { per } \mathrm{ce}\end{array}$ & & $=25$ & & & & & & & \\
\hline
\end{tabular}

Table.2 Extent of adoption of fennel production practices by the respondents

\begin{tabular}{|c|c|c|c|c|c|c|c|c|c|}
\hline \multirow{3}{*}{ S. No } & \multirow{3}{*}{ Aspect } & \multirow{2}{*}{\multicolumn{2}{|c|}{$\begin{array}{c}\text { Marginal } \\
\text { farmers }\end{array}$}} & \multirow{2}{*}{\multicolumn{2}{|c|}{ Small farmers }} & \multirow{2}{*}{\multicolumn{2}{|c|}{ Large farmers }} & \multicolumn{2}{|l|}{$n=120$} \\
\hline & & & & & & & & To & \\
\hline & & MPS & Rank & MPS & Rank & MPS & Rank & MPS & Rank \\
\hline 1. & Soil and field preparation & 85.00 & iv & 93.33 & iii & 85.83 & $\mathbf{v}$ & 88.06 & $\mathbf{v}$ \\
\hline 2. & High yielding varieties & 59.17 & ix & 94.17 & ii & 80.00 & vii & 77.78 & vii \\
\hline 3. & Seed treatment & 60.00 & viii & 82.50 & iv & 65.00 & ix & 69.17 & $\mathbf{x}$ \\
\hline 4. & Time of sowing & 77.50 & $\mathbf{v}$ & 100.00 & $\mathbf{i}$ & 100.00 & $\mathbf{i}$ & 92.50 & iii \\
\hline 5. & Seed rate and spacing & 74.06 & vi & 79.38 & vii & 78.44 & viii & 77.29 & viii \\
\hline 6. & Fertilizer application & 68.13 & vii & 76.88 & viii & 88.75 & iv & 77.92 & vi \\
\hline 7. & Irrigation management & 100.00 & $\mathbf{i}$ & 100.00 & i & 100.00 & $\mathbf{i}$ & 100.00 & $\mathbf{i}$ \\
\hline 8. & Weed management & 95.00 & ii & 100.00 & $\mathbf{i}$ & 95.00 & iii & 96.67 & ii \\
\hline 9. & Plant protection measures & 57.50 & $\mathbf{x}$ & 80.00 & $\mathbf{v}$ & 82.50 & vi & 73.33 & ix \\
\hline 10 & $\begin{array}{l}\text { Harvesting, threshing and } \\
\text { storage }\end{array}$ & 94.00 & iii & 79.50 & vi & 97.50 & ii & 90.33 & iv \\
\hline & Overall & 75.89 & & 84.76 & & 85.73 & & 82.12 & \\
\hline
\end{tabular}

MPS = Mean per cent score 
Table.3 Comparison of adoption of fennel cultivation practices among different categories of farmers

\begin{tabular}{|l|c|l|l|c|}
\hline Source of variation & d.f. & \multicolumn{1}{|c|}{ SS } & \multicolumn{1}{c|}{ MSS } & 'f' value \\
\hline Between the categories of farmers & 2 & 226.07 & 113.03 & $10.3057^{*}$ \\
\hline Error & 117 & 1283.27 & 10.9681 & \\
\hline Total & 119 & 2003.79 & & \\
\hline
\end{tabular}

* Significant at 1 per cent level

Mean value table

\begin{tabular}{|c|l|c|c|c|}
\hline S. No. & Categories of farmers & Mean value & CD & SEM \\
\hline 1. & Marginal farmers & 23.53 & & \\
2. & Small farmers & 26.28 & 0.232 & 0.083 \\
3. & Large farmers & 26.58 & & \\
\hline
\end{tabular}

The data presented in table 1 indicate that 28.33 per cent of the total respondents were in the medium level of adoption group, whereas 24.17 per cent respondents were in low adoption group and remaining 47.50 per cent fennel growers were observed in the category of high level of adoption about fennel production technology.

Further, among the various categories of fennel growers, it was observed that 22.50 per cent marginal farmers, 60.00 per cent small farmers and 60.00 per cent large farmers were in the high adoption category. Whereas, 27.50 per cent marginal farmers, 27.50 per cent small farmers and 30.00 per cent large farmers were reported in medium adoption group. Likewise, 50.00, 12.50 and 10.00 per cent marginal, small and large farmers possessed low level of adoption respectively about fennel production technology.

With the results at hand, it could be concluded that there existed a wide adoption gap among fennel farmers of the study area. The considerable gap was observed in all the category of respondents with little variation.

Meena (2010) found that 11.88 per cent farmers were high adopters, 37.50 per cent farmers were low level adopters and 50.62 per cent farmers were in the category of medium adopters of coriander production technology.

$\begin{aligned} & \text { Aspect-wise level of } \\ & \text { recommended } \\ & \text { technology }\end{aligned}$
fennel $\begin{array}{r}\text { adoption of } \\ \text { production }\end{array}$

Individual aspect wise level of adoption of fennel growers was worked out. For this, mean per cent score of each practice was calculated. The results are presented in table 2.

The data presented in table 2 show that large farmers of the study area possessed 88.06 per cent of adoption about soil and field preparation aspect of fennel production technology whereas, adoption by small and marginal farmers about this practice was comparatively less with 93.33 per cent and 85.00 per cent. The adoption about this aspect at fourth ranked by the marginal, third ranked by small and fifth ranked by large farmers.

The extent of adoption about high yielding varieties of fennel, the large farmers possessed 80.00 per cent of adoption about improved fennel varieties, whereas adoption of small and marginal farmers about this practice was comparatively less with 94.17 and 59.17 per cent respectively. It was 
observed that majority of the farmers had adoption about the name of varieties of fennel namely RF-101, RF-125, DEEPAK, GF-1 and GF-2. They were fully acquainted with duration and average yield of these recommended varieties of fennel in the study area. The adoption about this aspect at ninth ranked by the marginal, second ranked by small and seventh ranked by large farmers.

The adoption about Seed treatment, it was noted that marginal, small and large had adoption $60.00,82.50$ and 65.00 per cent MPS, respectively. The adoption about this aspect at eight ranked by the marginal, fourth ranked by small and ninth ranked by large farmers.

The adoption about Time of sowing, it was noted that marginal, small and large farmers had adoption about 77.50, 100.00 and 100.00 per cent, respectively. The adoption about this aspect was ranked fifth by the marginal and first by small and large farmers.

Regarding adoption about seed rate and spacing, it was noted that marginal, small and large farmers had adoption up to $74.06,79.38$ and 78.44 per cent extent, respectively. The above practice was ranked sixth by marginal and seventh by small farmers and eighth by large respondents. Majority of the respondents from all categories of farmers had full adoption of recommended seed rate $12-15 \mathrm{~kg} / \mathrm{ha}$ and plant to plant distance $10-$ $15 \mathrm{~cm}$ and row to row distance $40 \mathrm{~cm}$ as the most appropriate spacing for fennel. In case of fertilizers application, marginal, small and large farmers had 68.13, 76.88 and 88.75 per cent adoption and were ranked seventh by marginal, eighth by small and fourth by large farmers respectively. Whereas in case of irrigation management, all marginal, small and large farmers had cent per cent adoption and ranked first by all categories (marginal, small, large) farmers.
Regarding adoption of weed management practice it was placed at second rank by marginal farmers, at first rank by small farmers and at third rank by large farmers with 95.00, 100.00 and 95.00 MPS, respectively. The adoption about quantity of chemicals used in weed management was observed poor in the study area.

Regarding adoption about plant protection measures, it was found that marginal, small and large farmers had adoption to the extent of $57.50,80.00$ and 82.50 per cent, respectively. The table 2 clearly shows that all the categories of farmers had high adoption about plant protection measures and this aspect was ranked tenth by marginal and sixth by large farmers and fifth by small farmers. It means that fennel growers were acquainted with plant protection measures; they have fair adoption about insect-pest of fennel in comparison to chemicals quantity used to control them. The adoption of harvesting, threshing and storage, was found 94.00, 79.50 and 97.50 per cent by marginal, small and large farmers, respectively. This aspect was ranked third by the marginal, sixth by small and second by large farmers.

From the above discussion, it could be concluded that the level of adoption by marginal farmers was 75.89 per cent while by small farmers the extent of adoption was 84.76 per cent in all the improved practices of fennel cultivation, whereas, the extent of fennel practices by large farmers was 85.73 per cent. Further, it was noted that large farmers had more of adoption than marginal farmers and small farmers about almost all the fennel cultivation practices, still there is a gap in the adoption of improved fennel production technology.

The present finding is in conformity with that of Singh (2005) how studied the extent of adoption of various technologies in cumin 
(Cuminum cyminum) by farmers in the arid zone of the state and found that the majority $(62.5 \%)$ of farmers had adopted various production technologies to a medium level.

Comparison of adoption among marginal, small and large farmers with respect to recommended fennel production technology

To find out the variation or similarity in the adoption by marginal farmers, small farmers and large farmers about improved fennel production technology, ' $\mathrm{f}$ ' test was applied. The results were presented in table 3 .

\section{Hypothesis}

$\mathbf{N H}_{02}$ : There is no difference among the different categories of the farmers with respect to adoption of improved fennel production technology.

$\mathbf{R H}_{\mathbf{0 2}}$ : There is difference among the different categories of the farmers with respect to adoption of improved fennel production technology.

The data presented in table 3 reveal that the calculated ' $\mathrm{f}$ ' value (10.3057) is higher than tabulated ' $\mathrm{f}$ ' value Thus, the null-hypothesis $\left(\mathrm{NH}_{02}\right)$ is rejected and alternative hypothesis entitled "there is a difference among the different categories of farmers with respect to adoption of improved fennel production technology" was accepted. It means that there existed difference among the three categories of farmers with respect to adoption of fennel production technology. As explained earlier, the adoption level difference between large, small and marginal farmers may be due to the fact that large farmers of the study area are more educated, possess more knowledge of fennel technology The cumulative effect of all these factors might have led to comparative higher knowledge among large farmers.

\section{Adoption of recommended production technology of fennel by the farmers}

In conclusion findings indicated that 28.33 per cent of the total respondents were in the medium level of adoption group, whereas 24.17 per cent respondents were in low adoption group and remaining 47.50 per cent fennel growers were be observed in the category of high level of adoption about fennel production technology. It was observed that the extent of adoption among marginal farmers ranged from 57.50 to 100.0 per cent, whereas in case of small farmers and large farmers it was from 76.88 to 100.00 and 65.00 to 100.00 per cent in all the practices of fennel production respectively. Further, it was observed that large and small farmers had comparatively more extent of adoption than marginal farmers. The study indicated that there was difference among marginal, small and large farmers with respect to adoption of fennel practices.

\section{References}

Anonymous. 2010-11. Indian Economy.

Anonymous. 2010-11. Spices Board and CMIE.

Anonymous. 2011-12. Agricultural Statistics, Directorate of Economics and Statistics,

Anonymous. 2011-12. Vital Agriculture Statistics, Dept. of Agriculture, GOR, Pant Krishi Bhawan, Jaipur.

Chandawat, M.S. 1997. "Knowledge and adoption of improved practices of cumin production technology in the Jalore district of Rajasthan". M. Sc. Thesis (Unpub), Rajasthan Agriculture University, Bikaner.

Department of Agriculture and Cooperation, Government of India, New Delhi.

Jaitawat, V.S. 2006. "Knowledge and adoption of recommended cumin cultivation technology among the farmers of Jodhpur region of 
Rajasthan", Ph.D. Thesis (Unpub.), Rajasthan Agriculture University, Bikaner.

Jat, S.L. 2008. "Knowledge and adoption of improved cultivation practices of fenugreek by the farmers of Dataramgarh tehsil in sikar district of Rajasthan”. M.Sc. (Ag.) Thesis (Unpub.), Rajasthan Agriculture University, Bikaner.

Meena, R.P., Sharma, C., Sharma, V.P., Bhimawat, B.S. and Dadheech, B.S. 2006. Adoption of improved Ajwain production practices among the farmers of Dungla Tehsil in Chittorgarh district of Rajasthan. Rajasthan J. Extension Education, 14: 47-51.

Meena, D.K. 2010. Knowledge and adoption of coriander (Coriandrum sativum L.) production technology by the tribal and non-tribal farmers in Jhalawar district of Rajasthan. M.Sc. (Ag.) Thesis (Unpub.), SKRAU, Bikaner, Campus, Bikaner.

National Horticulture Mission 2011-12

Nagar, S.N. 2006. "Knowledge and adoption of recommended fennel cultivation technology among the farmers of Atru Tehsil in Baran district of Rajasthan".
M. Sc. Thesis (Unpub), Maharana Pratap University of Agriculture and Technology, Udaipur.

Nagar, S.N., Chauhan, M.S., Sharma, F.L. and Sharma, V.P. 2008. Adoption of recommended coriander cultivation technology among the farmers of Atru tehsils of Baran district of Rajasthan. Rajasthan J. Extension Education, 16: 190-194.

Patel, M.R. 1993. "A study on extent of adoption of recommended plant protection measures by chilli growers in Kheda district of Gujarat state". M.Sc. (Ag.) Thesis, G.A.U., Campus- Anand.

Patel, V.T., Prajapati, M.R., Chaudhari, N.V. and Joshi, K.M. 2004. Knowledge and adoption recommended cumin production technology by the farmers of North Gujarat. Gujarat J. Extension Education, 8\&9: 141-145.

Venkataramulu, M. 2008. Knowledge, adoption and marketing behavior of chilli in Guntur district of Andhra Pradesh. M.Sc. (Ag.) thesis submitted to Acharya N.G. Ranga Agricultural University, Hyderabad.

Vital Agriculture Statistics (2011-12)

\section{How to cite this article:}

Sunil Kumar Sharma, N.K. Sharma and Kumawat, S.R. 2017. Adoption of Recommended Production Technology of Fennel Cultivation by the Farmers in Nagaur District of Rajasthan. Int.J.Curr.Microbiol.App.Sci. 6(3): 969-976. doi: https://doi.org/10.20546/ijcmas.2017.603.115 